\title{
Seed Bank Variation under Contrasting Site Quality Conditions in Mixed Oak Forests of Southeastern Ohio, USA
}

\author{
Christine J. Small ${ }^{1}$ and Brian C. McCarthy ${ }^{2}$ \\ ${ }^{1}$ Department of Biology, Radford University, Radford, P.O. Box 6931, VA 24142, USA \\ ${ }^{2}$ Department of Environmental and Plant Biology, Ohio University, Athens, OH 45701, USA
}

Correspondence should be addressed to Christine J. Small, cjsmall@radford.edu

Received 31 August 2009; Accepted 3 February 2010

Academic Editor: Marc D. Abrams

Copyright () 2010 C. J. Small and B. C. McCarthy. This is an open access article distributed under the Creative Commons Attribution License, which permits unrestricted use, distribution, and reproduction in any medium, provided the original work is properly cited.

\begin{abstract}
Seed bank composition was sampled in 192-2.5 $\mathrm{m}^{2}$ quadrats, established in six regenerating clearcut ( $\sim 7$ years) and six secondgrowth $(\sim 125$ years) mixed-oak forest stands in southeastern Ohio. Seed bank and aboveground composition diverged markedly (Sørensen's coefficient $<10 \%$ ), emphasizing the importance of fast-growing, early-successional germinants to early ecosystem recovery. Seed richness was significantly $(P<.01)$ higher in clearcut stands, suggesting declining richness with stand age. Richness estimations $28 \%-60 \%$ higher than observed values demonstrated high seed bank heterogeneity, emphasizing the need for intensive sampling to assess temperate forest seed bank variation. Site quality (topographic aspect) strongly influenced seed bank composition, with greater importance of early-successional trees, thicket-forming shrubs, and nonnative species on mesic sites. Thus, forest seed banks are likely to play an important, site-dependent role in shaping competitive environments for commercially important timber species after harvesting and soil disturbance and have the potential for marked influence on postharvest forest development.
\end{abstract}

\section{Introduction}

Management priorities in US National Forests have changed markedly over the past century, with current policy emphasizing management of forests as intact and functioning ecosystems $[1,2]$. This ecosystem-based approach seeks to maintain forest productivity and production of goods and services, while protecting the physical, chemical, and biological processes associated with healthy ecosystem function (e.g., soil and water quality, nutrient cycling, and biological diversity) [2-4]. As disturbance is an essential component of forested ecosystems, influencing forest structure, function, and development, it follows that management practices based on a comprehensive understanding of forest disturbance and recovery processes should be the most successful in regenerating preharvest forest structure and composition and minimizing ecosystem impacts $[1,5]$.

Designing ecosystem-based management plans for largescale, stand-initiating harvests are particularly challenging, as postharvest conditions may be quite different from similarly scaled natural disturbances $[3,6]$. Like natural canopyopening disturbance, stand-level harvest substantially alters site conditions (e.g., light availability, air and soil temperatures, soil moisture, nitrification, organic content), which in turn influences survival and reservoirs of plant species diversity in the postharvest community [7-9]. However, complete removal of overstory trees and soil disturbance during traditional stem-only or whole-tree clearcutting has the potential to significantly alter stand development patterns by reducing or eliminating advance regeneration (e.g., formerly suppressed seedlings and saplings and root- and stumpsprouts) and increasing the importance of germinating seeds during early ecosystem recovery $[3,10,11]$.

The importance of the soil seed bank to temperate forest recovery following large-scale disturbance is widely recognized. Early-successional, short-lived species typically dominate forest seed banks and germinate quickly in response to increased light, fluctuating temperatures, and low $\mathrm{CO}_{2}$ concentrations, facilitating rapid revegetation and resource capture (esp. water and nutrient runoff) [7, 12-14]. 
Yet the seed bank contributes little to the direct regeneration of late successional deciduous forest species, as trees and forest herbs rarely form long-term persistent seed banks [15-18]. Nonetheless, significant seed bank contributions to early-successional seres suggest that seed composition may have pronounced influences on the development of postharvest forest communities. Early-successional, herbaceousdominated understories have been shown to act as speciesspecific "filters" to forest regeneration, inhibiting the establishment and growth of many commercially-important and shade-intolerant hardwood seedlings $[19,20]$. Even when advanced regeneration of target species is present, dense layers of understory vegetation can severely inhibit hardwood regeneration $[6,21]$. This issue has been well studied in oaks (Quercus spp.), where understory competition for above- and below ground resources (esp. light) is considered a primary cause of postharvest regeneration failure, particularly on high quality sites $[22,23]$.

Whereas the importance of understory competition to forest regeneration is widely recognized, the potential for buried seeds to influence postharvest forest dynamicsthrough the shaping of early-successional communities and resulting competitive interactions-has received little attention, especially within the compositionally diverse mixed mesophytic forest region $[15,24-26]$. In particular, little is known about the potential for buried seeds to influence postharvest forest regeneration under differing site quality conditions (e.g., [27]). It is widely recognized that much of the site quality variation that occurs across topographically dissected landscapes (e.g., moisture, temperature, radiation, soil depth, and fertility) can be accounted for by slope aspect, with generally more mesic conditions (e.g., moisture, fertility) on NE slopes and more xeric conditions on SW slopes in north temperate regions [28-32]. Given the pronounced influence of site quality on both understory [33$37]$ and overstory $[12,22,23,38]$ composition, productivity, and regeneration success, similar variation in seed bank composition and diversity may be expected across the landscape. Thus, our objectives were to examine variations in seed bank and aboveground vegetation relative to topographic aspect in recently clearcut and mature second-growth mixed oak forests and evaluate potential contributions of the seed bank to postharvest forest development under these contrasting site quality conditions.

\section{Materials and Methods}

2.1. Study Site. Field sampling was conducted at the Waterloo Wildlife Research Station (WWRS; $39^{\circ} 21^{\prime} 8^{\prime \prime} \mathrm{N}$, $82^{\circ} 16^{\prime} 57^{\prime \prime} \mathrm{W}$ ), a 505 ha state-owned research area in the Low Hills Belt section [39] of the Unglaciated Allegheny Plateau of southeastern Ohio, USA [40]. Topographically, this region is highly dissected, with moderate to steep slopes $(20 \%-70 \%)$ and ridgetop elevations of 280 to $320 \mathrm{~m}$. The vegetation of WWRS lies in the mixed mesophytic forest association of the unglaciated eastern deciduous forest region [39]. Mature second-growth forests are dominated by mixed oaks (Quercus spp.) and hickories (Carya spp.) on ridgetops and south-facing slopes and mesophytic species (e.g., Fagus grandifolia, Liriodendron tulipifera, Acer saccharum, Fraxinus americana, and Prunus serotina) on lower and north-facing slopes [41].

Prior to anthropogenic disturbance, the land occupied by WWRS was heavily forested. By the late 1800s and early 1900s, however, much of the region (including WWRS) was under cultivation or pasture and large areas experienced heavy timber harvesting [32]. Today, the overstory at WWRS is relatively even-aged ( 125 years). In our study sites, these second-growth stands are dominated by Acer rubrum, Quercus prinus, Q. alba, Q. velutina, Q. coccinea, Fagus grandifolia, and Nyssa sylvatica. Young revegetating clearcut stands also are present ( $\sim 7$ years), similarly dominated by $A$. rubrum and $Q$. prinus, but with greater importance of Liriodendron tulipifera, Prunus serotina, and Sassafras albidum [41].

2.2. Field and Greenhouse Methods. To sample seed bank and aboveground vegetation characteristics, permanent $2.5 \mathrm{~m}^{2}$ circular quadrats were established in six upland, naturally regenerating clearcut stands (CC, $\sim 7$ years; late stand initiation stage) and six upland second-growth forest stands (SG, 125 years; understory reinitiation stage) [5]. Sixteen replicate quadrats $(n=16)$ were established in each of the 12 stands, in a stratified-random arrangement $(N=192)$ [41]. Each stand had a minimum area of 1.75 ha $(100 \times 175 \mathrm{~m})$ and was uniformly treated (entirely CC or SG). Each clearcut stand was located within $100 \mathrm{~m}$ of one of the six secondgrowth forest stands (minimum $50 \mathrm{~m}$ buffer between CC and SG quadrats) and displayed similar ranges of elevation, slope angle, and topographic aspect. These pairs of clearcut and second-growth stands were treated as statistical blocks when examining species-site relationships relative to stand age.

Each quadrat was assigned to one of three aspect categories, shown to represent gradients of soil moisture, depth, and fertility across this study site $[37,41]$. Aspect categories were as follows: northeast $(\mathrm{NE})=345.5^{\circ}$ to $104.5^{\circ}$ aspect $\left(119^{\circ}\right.$ range around due $\left.\mathrm{NE}\left(45^{\circ}\right)\right)$, southwest $(\mathrm{SW})=165.5^{\circ}$ to $284.5^{\circ}$ aspect $\left(119^{\circ}\right.$ range around due SW $\left.\left(225^{\circ}\right)\right)$, and intermediate (INT) $=105^{\circ}$ to $165^{\circ}$ and $285^{\circ}$ to $345^{\circ}$ aspect $\left(60^{\circ}\right.$ ranges around due SE $\left(135^{\circ}\right)$ and NW $\left.\left(315^{\circ}\right)\right)$. Thus, six aspect/stand age classes were evaluated: NE-SG $(n=28)$, INT-SG $(n=27)$, SW-SG $(n=41)$, NE-CC $(n=29)$, INTCC $(n=34)$, and SW-CC $(n=33)$. In each $2.5 \mathrm{~m}^{2}$ quadrat, all vascular plant species were inventoried in late April 1998 and late June 1998, to capture peak growth of spring ephemeral herbs and graminoids/composites, respectively. One seed bank sample, including soil and leaf litter, was collected immediately adjacent to each vegetation quadrat ( $n=192)$ in early March 1999, to allow natural cold stratification of seeds from the 1998 growing season. Samples were extracted using a $10 \times 10 \times 5 \mathrm{~cm}$ deep $\left(500 \mathrm{~cm}^{3}\right)$ metal frame. Collected seed bank samples were placed in plastic bags and stored at $4^{\circ} \mathrm{C}$ until all samples were obtained.

Seed bank composition was assessed using the seedling emergence method. This technique is considered relatively accurate and the most appropriate for plant communities in which high seed richness is expected ([13, 42, 43], but see Baskin and Baskin [44]). Collected samples were 
TABle 1: Mean, total, and Jackknife estimated species richness of aboveground vegetation in 192 quadrats established in six revegetating clearcut (CC; $\sim 7$ years) and six second-growth (SG; $\sim 125$ years) forest stands at WWRS. Asterisk $(*)$ indicates significant difference in CC and SG richness $(P<.05)$. Letters indicate significant difference among CC/SG topographic aspect classes $(P<.05)$.

\begin{tabular}{|c|c|c|c|c|c|c|c|}
\hline & \multirow{2}{*}{ Mean Richness* } & \multicolumn{3}{|c|}{ Mean Richness by Aspect Class } & \multirow{2}{*}{ Total Richness } & \multirow{2}{*}{$\begin{array}{c}\text { Jackknife } 1 \\
\text { Total Richness }\end{array}$} & \multirow{2}{*}{$\begin{array}{c}\text { Jackknife } 2 \\
\text { Total Richness }\end{array}$} \\
\hline & & SW & INT & $\mathrm{NE}$ & & & \\
\hline $\mathrm{CC}$ & 14.7 & $14.1^{(\mathrm{ac})}$ & $16.0^{(\mathrm{a})}$ & $13.9^{(\mathrm{ac})}$ & 118 & 134.8 & 120.8 \\
\hline SG & 12.8 & $11.3^{(\mathrm{b})}$ & $15.9^{(\mathrm{a})}$ & $12.1^{(\mathrm{bc})}$ & 104 & 135.0 & 124.9 \\
\hline Total & & & & & 132 & & \\
\hline
\end{tabular}

concentrated using an $8 \mathrm{~mm}$ sieve to remove vegetative propagules, leaf litter, and other coarse materials and increase emerging seedling density, as suggested by Ter Heerdt et al. [45]. Samples were spread over $2-3 \mathrm{~cm}$ of vermiculite/potting medium in $20 \times 20 \times 6 \mathrm{~cm}$ aluminum trays. Four trays containing only vermiculite/potting medium were used to detect the presence of wind-borne seeds. Trays were placed on greenhouse benches and watered as necessary to maintain soil moisture. Seedling emergence was monitored from March through November 1999. As seedlings emerged, each was identified to species and removed. If identification was not possible, seedlings were transplanted to pots and grown to maturity. Voucher specimens were retained for all species. Each month, dilute liquid fertilizer was applied to stimulate seedling growth and trays were randomly rearranged to control location effects [13]. After completion of emergence studies, five trays were randomly selected from each aspect/stand age class ( 5 trays $\times 6$ aspect/stand age classes; thus, $n=30$ ) and soil examined for ungerminated seeds. Seeds located were soaked in water (20 hours), seed coats were punctured, and seeds were immersed in $1 \%$ neotetrazolium chloride solution (48 hours) to test for viability $[46,47]$. All ungerminated seeds found to be viable were represented by emerged species. Nomenclature for aboveground and seed bank species follows Gleason and Cronquist [48].

2.3. Data Analysis. Mean frequency was calculated for each seed bank and aboveground species by aspect/stand age class. Revegetating clearcut and second-growth forest diversity were assessed as mean (per seed bank sample or aboveground quadrat) and total species richness. Two-way ANOVA tests were used to examine the effects of stand age (CC versus SG; fixed effect), aspect position (NE, INT, SW; fixed effect), and the interaction of these on seed bank and aboveground richness. Stand was treated as a random effect (block). Richness data were $\log _{10}$ transformed to meet normality and equal variance assumptions. Treatment means for significant ANOVAs were compared using a posteriori Bonferroni multiple comparison procedures. All ANOVAs were conducted using NCSS software [49].

To evaluate the adequacy of seed bank and understory sampling, bootstrap-derived species-area curves were created by subsampling the data set to determine mean richness at each possible subsample size. In addition, total clearcut and second-growth seed bank and understory richness values were compared to two nonparametric, incidencebased richness estimators: (1) first-order Jackknife, which incorporates the number of uniques (species occurring in a single quadrat) and the number of quadrats sampled [50, 51], and (2) second-order Jackknife, which incorporates the number of uniques, duplicates (species occurring in exactly two quadrats), and sample quadrats $[52,53]$. In accordance with Palmer [51, 53], Chazdon et al. [54], and others, these resampling techniques were used to reduce sampling bias and create more robust richness estimations by more heavily weighting rare or infrequent species for a given sample size. Species-area curves and estimated richness values were calculated using PC-ORD software [55].

Compositional variation among aboveground and seed bank samples was examined using hierarchical, polythetic, and agglomerative cluster analysis, with UPGMA group linkage and Sørensen's dissimilarity method ([56]; PC-ORD software [55]). Sørensen's Community Coefficient was used to estimate the compositional similarity of seed bank versus aboveground samples in clearcut and second-growth forest stands. The index is calculated as $2 c /(a+b+2 c)$, where $a$ is the number of species unique to sample $a, b$ is the number of species unique to sample $b$, and $c$ is the number of species shared by both samples. The relationship of seed bank composition to vegetation, topography, and microenvironmental variables was examined using Canonical Correspondence Analysis (CCA [55]). CCA is a direct ordination technique that provides simultaneous evaluation of vegetation and environmental data [57]. Variables included in the initial CCA were aspect, slope angle, leaf litter depth, air temperature, relative humidity, spring light availability, soil $\mathrm{NO}_{3}, \mathrm{P}$, $\mathrm{K}, \mathrm{Ca}, \mathrm{Mg}$, and $\mathrm{Al}$, soil moisture, organic matter content, silt, clay, $\mathrm{C}, \mathrm{N}$, and $\mathrm{C}: \mathrm{N}, \mathrm{pH}$, soil compaction, tree basal area and density, and sapling, seedling, herbaceous cover. (See Small and McCarthy [41] for complete descriptions of soil analyses and vegetation measures.) Quadrat aspect was cosine transformed to range from 0 (SW) to 2 (NE) for use in CCA [58]. All variables were $\log _{10}$ transformed to reduce outlier influence and provide greater weight to changes in resource availability (e.g., soil nutrients) at low concentrations [59]. Highly correlated variables and those only weakly associated with the first three CCA axes were removed from final CCAs to produce the most parsimonious ordinations, in accordance with Ter Braak [57] and Palmer [59].

\section{Results}

3.1. Species Richness. Plant species richness aboveground was more than twice that of the seed bank (132 versus 63 spp.) and, in both strata, appeared to decline with stand age (Tables 1 and 2; Figure 1). Mean richness per quadrat/sample 


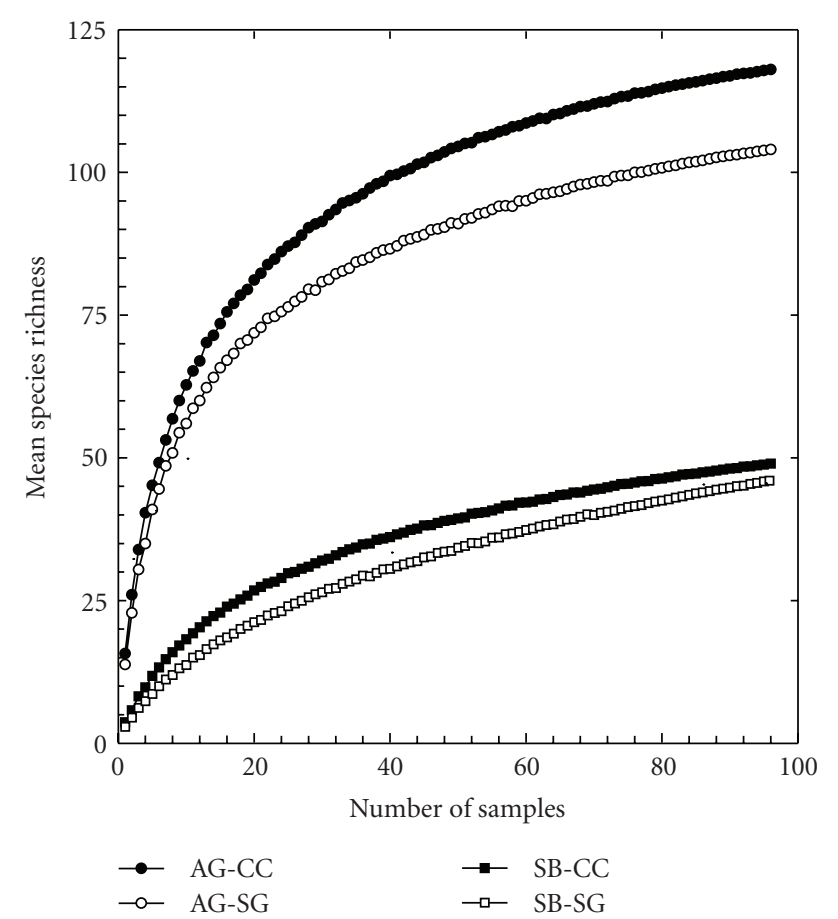

Figure 1: Bootstrap-derived species-area curves $( \pm 2 \mathrm{SD}$; dotted lines) for $96-2.5 \mathrm{~m}^{2}$ aboveground (AG) and seed bank (SB) samples in revegetating clearcut (CC; $\sim 7$ years) and second-growth (SG; $\sim 125$ years) forest stands at WWRS, Athens County, Ohio, USA.

for both aboveground vegetation and the seed bank were significantly higher in younger revegetating clearcuts than in more mature forests $(P<.05$ aboveground, $P<.01$ seed bank; Tables 1 and 2). Similarly, total richness aboveground (CC $=118$ versus $S G=104$ spp.) and in the seed bank (CC = 49 versus $\mathrm{SG}=46 \mathrm{spp}$.) was slightly lower in mature stands. Richness estimators (Jackknife 1, Jackknife 2) supported these differences aboveground (greater richness in younger stands) and suggested that a relatively small proportion of species remained unaccounted for based on our sampling efforts $(2 \%-12 \%$ in CC; $17 \%-23 \%$ in SG; Table 1$)$. In contrast, Jackknife estimations of seed bank richness were markedly higher than observed values, suggesting that our samples failed to account for one quarter to one third of the species likely present $(22 \%-28 \%$ in CC; $29 \%-38 \%$ in SG; Table 2). Further, richness estimators suggested higher seed bank richness in later successional stands. Convergence of species-area curves for clearcut and forest seed banks also suggests that greater sampling may produce higher belowground richness values in mature stands (Figure 1).

3.2. Species Composition. Species composition differed markedly between seed bank and aboveground samples (Sørensen's coefficient of similarity $<10 \%$ ) and suggested increasing compositional divergence with stand age. In both clearcut and second-growth stands, cluster analysis showed nearly complete divergence of seed bank and aboveground vegetation although above- to belowground similarity was slightly higher in younger stands (Sørensen's coefficient CC =

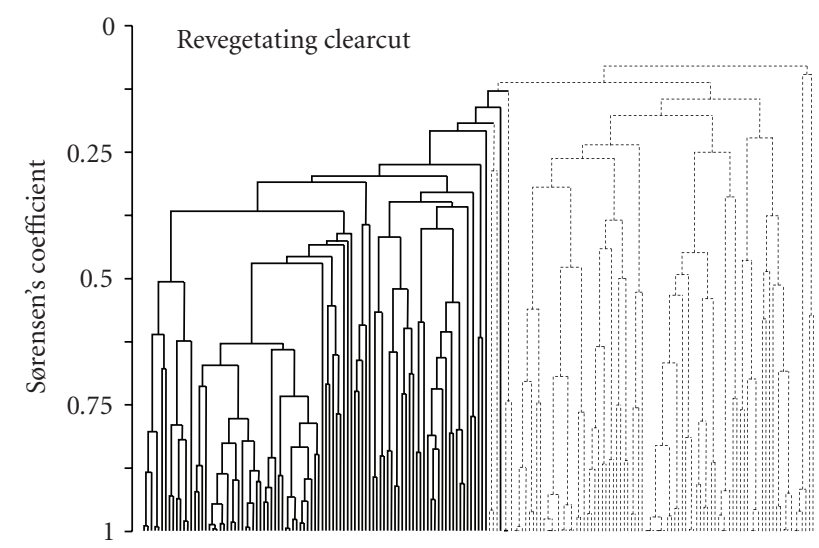

(a)

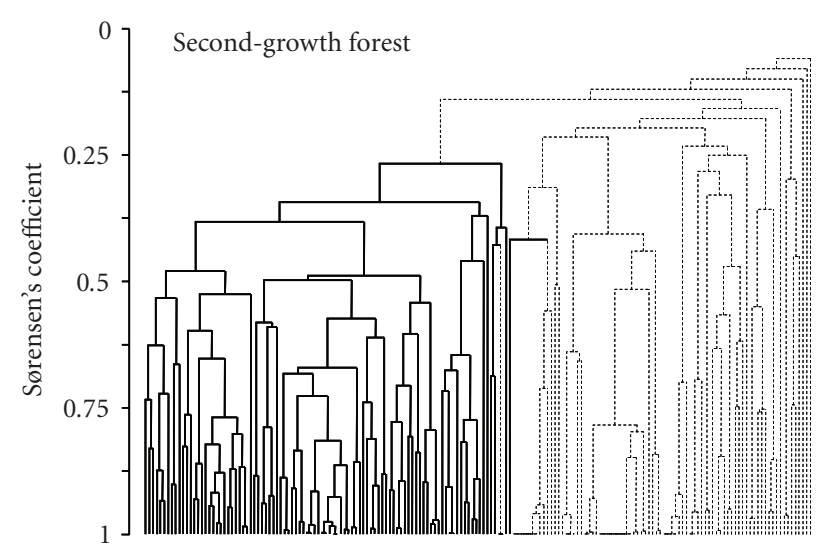

(b)

FIGURE 2: Dendrogram representing UPGMA cluster analysis of aboveground (broken) and seed bank (solid) samples in revegetating clearcut and second-growth forest quadrats at WWRS.

$26.6 \%, S G=21.6 \%$; Figure 2). Compositional separation of seed bank and aboveground vegetation resulted largely from high frequency of early-successional annuals (e.g., Erechtites hieraciifolia, Acalypha rhomboidea, Solanum nigrum, Verbascum thapsus) and graminoids (Carex spp., Juncus tenuis, and Panicum spp.) in the seed bank and increased frequency of shade-tolerant perennial herbs (e.g., Aster spp., Desmodium glutinosum, Lysimachia quadrifolia, Polygonatum pubescens, Polystichum acrostichoides, and Potentilla simplex), shrubs (Rubus pensilvanicus, Smilax rotundifolia), and trees (Acer rubrum, Quercus prinus, Sassafras albidum) aboveground (Figure 3, Table 3).

Compositional trends within the seed bank (CCA ordination; Figure 4) showed marked influence of both stand age and topographic aspect, with revegetating clearcuts and second-growth forests separated along CCA Axis $1(\lambda=$ 0.349 ) and aspect categories grading from most mesic (NE) to most xeric (SW) along Axis $2(\lambda=0.267)$. Of our measured site variables, aspect had the most pronounced correlation with seed bank composition (Axis 2, $r=$ -0.923 ). Other important variables, each correlated with compositional variation along Axis 1 and reaching the greatest extent in young clearcut stands, were temperature 
TABLE 2: Mean, total, and Jackknife estimated species richness in 192 seed bank samples collected from six revegetating clearcut (CC; 7 years) and six second-growth (SG; 125 years) forest stands at WWRS. Double asterisk $(* *)$ indicates significant difference in CC and SG richness $(P<.01)$. Letters indicate significant difference among CC/SG topographic aspect classes $(P<.05)$.

\begin{tabular}{|c|c|c|c|c|c|c|c|}
\hline & \multirow{2}{*}{ Mean Richness** } & \multicolumn{3}{|c|}{ Mean Richness by Aspect Class } & \multirow{2}{*}{ Total Richness } & \multirow{2}{*}{$\begin{array}{c}\text { Jackknife } 1 \\
\text { Total Richness }\end{array}$} & \multirow{2}{*}{$\begin{array}{c}\text { Jackknife } 2 \\
\text { Total Richness }\end{array}$} \\
\hline & & SW & INT & NE & & & \\
\hline $\mathrm{CC}$ & 2.7 & $2.3^{(a)}$ & $3.1^{(a)}$ & $2.6^{(a)}$ & 49 & 62.9 & 67.8 \\
\hline SG & 1.9 & $1.4^{(\mathrm{b})}$ & $2.3^{(\mathrm{a})}$ & $2.1^{(\mathrm{a})}$ & 46 & 64.8 & 73.7 \\
\hline Total & & & & & 63 & & \\
\hline
\end{tabular}

$(r=0.849)$, light availability $(r=0.513)$, and tree density $(r=0.665$; Figure 4$)$. Cluster analysis of samples in our sixstand age/aspect classes emphasized topographic influences on seed bank and aboveground composition. After early divergence of seed bank and aboveground samples, cluster analysis showed consistent separation of samples from NE and SW aspect positions, both above- and belowground, regardless of stand age (Figure 5). Aboveground, these compositional variations were associated with increased frequency of Amphicarpaea bracteata, Anemonella thalictroides, Arisaema triphyllum, Cardamine concatenata, Cimicifuga racemosa, Geranium maculatum, Osmorhiza claytonii, Fraxinus americana, and Viburnum acerifolium from SW to NE slopes (both CC and SG stands), and higher frequency of graminoids and most woody seedlings (e.g., Lysimachia quadrifolia, Carex digitalis, Panicum spp., Liriodendron tulipifera, Quercus spp., Sassafras albidum, Vaccinium spp., and Smilax spp.) on SW slopes (Figure 3, Table 3). In the seed bank, species such as Phytolacca americana, Carex laxiflora, Rhus glabra, and Rubus spp. were more common on NE slopes (esp. CC); grasses (esp. Panicum spp.) were more widely distributed on SW slopes (Table 3).

3.3. Nonnative Species. The distribution of nonnative plant species was also strongly influenced by aspect, with remarkably similar trends aboveground and in the seed bank (Figure 6). Greater nonnative richness was found in the seed bank (9 spp., Cardamine hirsuta, Digitaria ischaemum, Glechoma hederacea, Polygonum convolvulus, Sida spinosa, Solanum nigrum, Trifolium pratense, T. repens, and Verbascum thapsus) than aboveground (6 spp., Cardamine hirsuta, Celastrus orbiculatus, Potentilla recta, Rosa multiflora, Taraxacum officinale, and Tussilago farfara; Table 3), yet nonnative plants were more common in aboveground quadrats (Figure 6). Recent harvesting appeared to increase the frequency of nonnative species, both aboveground and in the seed bank (Figure 6). The most pronounced influence, however, appeared to be that of site quality, with more mesic sites (INT and NE aspects) supporting greater frequencies of nonnative species, especially in younger stands, whereas more xeric sites (SW) had consistently low nonnative abundance (Figure 6).

\section{Discussion}

Our examination of buried seed distribution across naturally regenerating (stand initiating) and mature second-growth mixed oak stands showed four pronounced trends: (1) seed bank composition diverged markedly from that of aboveground vegetation, (2) observed seed bank richness was lower in later successional forests than in recently harvested stands, (3) despite intensive sampling (relative to most seed bank studies), richness estimators and species-area curves indicated high seed bank variability, supporting previous assertions that temperate forest seed banks often are undersampled, and (4) topographic aspect strongly influenced seed bank composition, including the prevalence of nonnative plant species. We discuss each of these findings and consider implications for postharvest forest regeneration below.

\subsection{Compositional Divergence of Seed Bank and Aboveground} Vegetation. One of the most widely supported generalizations concerning forest seed banks is that the composition of buried seeds diverges from that of aboveground vegetation $[14,15,60-62]$. Low compositional similarity of above- and belowground vegetation $(<10 \%)$ at our study site supports this generalization and suggests that mixed oak forests in the mixed mesophytic forest region are likely to follow this pattern. Furthermore, while younger stands ( $\sim 7$ years) showed slightly greater above- versus belowground compositional similarity, even the short time since clearcutting was sufficient for marked differentiation to occur (Figure 2; Table 3). As in other forest regions, the prevalence of fast-growing, early-successional species in the seed bank emphasizes the importance of buried seeds to ecosystem recovery following large-scale disturbance (Figure 3) $[8,12]$. In contrast, the markedly lower frequency and diversity of later successional species (trees and herbaceous perennials) reflects the inability of many of these species to form persistent seed banks and highlights the role of vegetative reproduction and postdisturbance seed dispersal in the regeneration of mature forest species $[17,44,63]$.

4.2. Increased Seed Bank Richness in Young Forests. Our results showed higher seed bank and aboveground richness in younger, revegetating clearcut stands than in later successional, second-growth forests, due primarily to greater importance of graminoids and nonnative species. Increases in aboveground diversity following clearcutting are consistent with Roberts and Gilliam ([9]; mesic sites), Bormann and Likens [8], Small and McCarthy [37], and others and have been linked to greater habitat heterogeneity and resource availability following disturbance $[5,64,65]$. Disturbance and associated heterogeneity also have been shown to increase ecosystem susceptibility to nonnative 


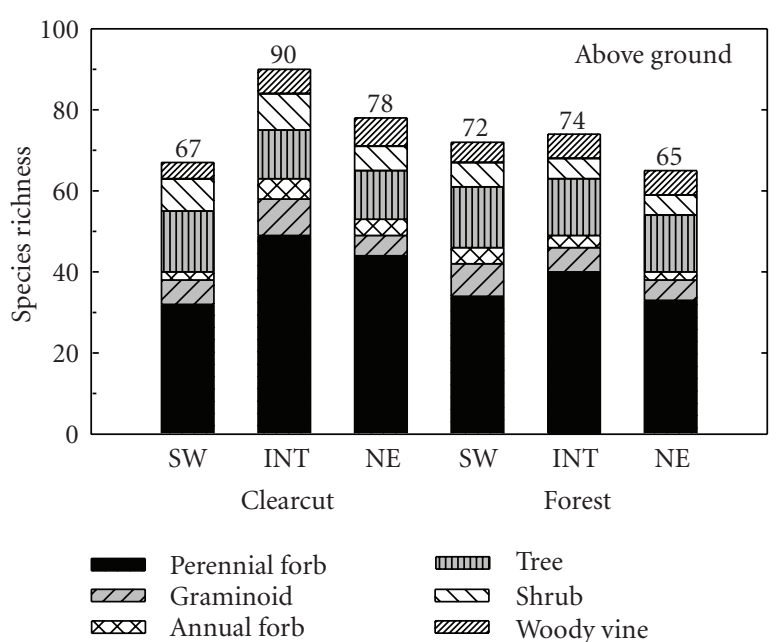

(a)

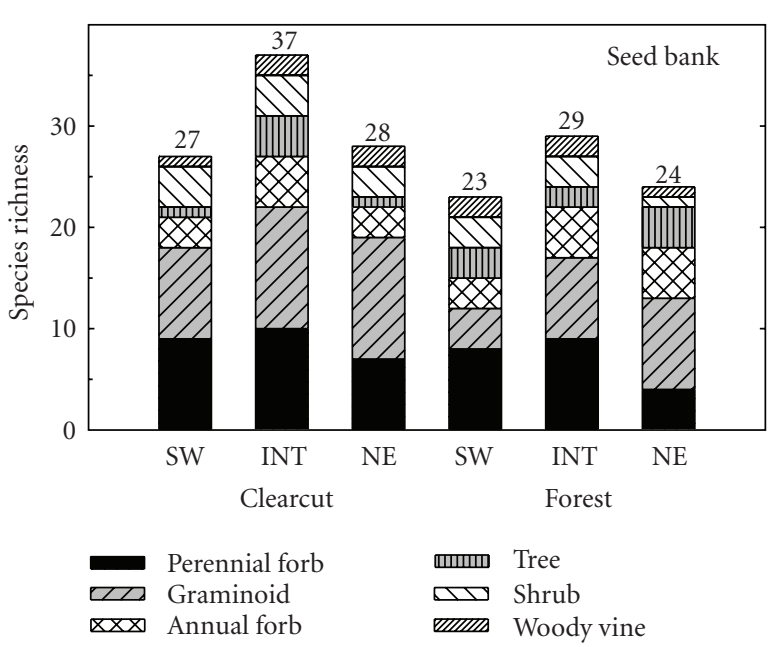

(b)

Figure 3: Aboveground and seed bank richness by life form in revegetating clearcut and second-growth forest samples at southwest (SW), intermediate (NW/SE; INT), and northeast (NE) aspect positions at WWRS. Note different scales of $y$-axes. See text for definitions of stand type/aspect classes. Life form designations follow Gleason and Cronquist [48].

species, reducing resource use and competition by resident vegetation and increasing the availability of resources to opportunistic invading species $[66,67]$. While the influence of microenvironmental variability on aboveground vegetation is widely recognized $[9,41,68]$, our results suggest comparable influences on seed dispersal and storage in the soil seed bank.

In contrast to generalizations about above- and belowground compositional divergence, generalizations about changes in seed bank diversity during forest succession have received limited support. Like our study, Pickett and McDonnell [15] suggest seed bank diversity to be higher early in forest succession and decline with canopy closure. Several chronosequence studies also have examined seed bank dynamics during deciduous forest succession $[12,60,69]$.

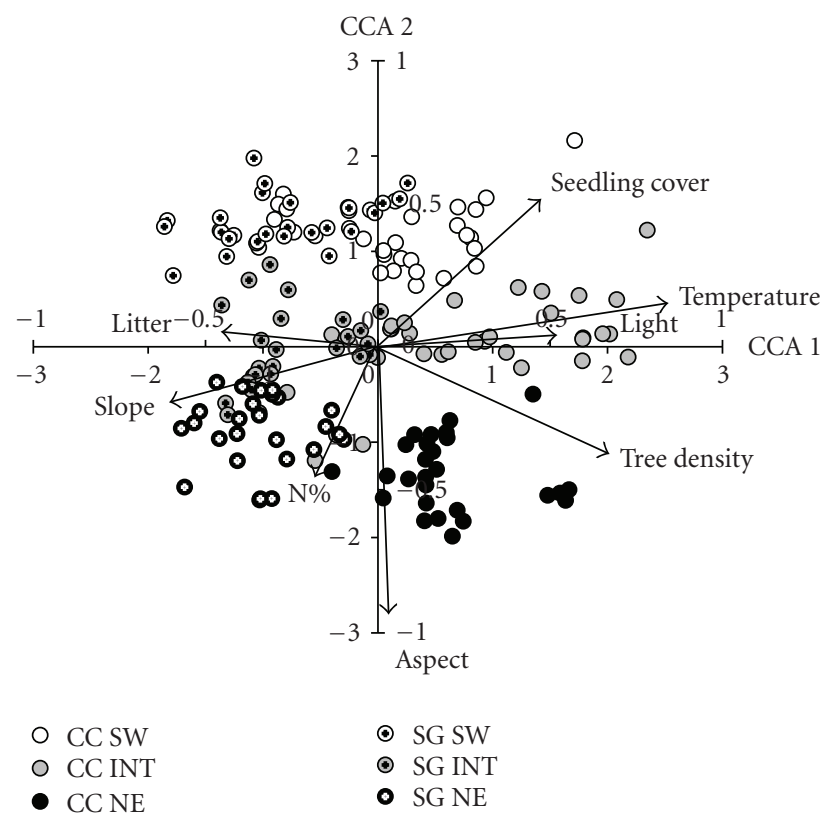

FIGURE 4: Canonical correspondence analysis (CCA) ordination of 192 seed bank samples by aspect class (see text) in revegetating clearcut and mature second-growth forest samples. See text for description of variables.

Whereas many of these studies document declines in seed bank density over time [14, 15], trends in seed bank richness vary widely. For example, Roberts and Vankat [69] found seed bank richness to decline during succession, yet indicated that seed bank richness may not decline if aboveground vegetation diversity is especially high. Stark et al. [70] indicate that changes in seed bank richness and heterogeneity depend more on spatial scale than time since disturbance. Trends in seed bank diversity during succession were similarly unclear at our study site, as Jackknife richness estimators contradicted observed trends and suggested that additional sampling may produce higher seed bank richness values in older forests (Table 2). If this is the case, the high diversity of aboveground vegetation at our study site ( $>100$ species in SG forest quadrats) may limit successional declines in seed bank diversity, as suggested by Roberts and Vankat [69].

4.3. Sampling Considerations for Seed Bank Variability. As in many seed bank studies, we found considerably lower richness in the seed bank than aboveground. Yet the 63 species of buried seeds we observed were markedly higher than those reported for most temperate forest communities [15]. This increased richness may reflect the relatively small number of seed bank studies conducted in the mixed mesophytic forest region $[15,25]$ or correspond to the exceptionally high aboveground diversity for which this region is noted $[39,69]$. An examination of experimentally thinned, burned, and untreated mixed oak stands in southeastern Ohio found similarly high seed emergence from samples collected in early spring (70 spp. in $80-0.01 \mathrm{~m}^{2}$ samples [26]). However, as in our study, poor representation of aboveground species in the seed bank suggests that aboveground diversity is not 
TABLE 3: Frequency of occurrence (\% of samples) for aboveground understory (herbaceous and woody seedling) and seed bank species in revegetating clearcut (CC) and second-growth (SG) forest samples by aspect category at WWRS. Only species with frequencies $>12 \%$ across all stand/aspect categories are shown. Asterisk $(*)$ indicates a nonnative species.

\begin{tabular}{|c|c|c|c|c|c|c|c|c|c|c|c|c|}
\hline \multirow[b]{3}{*}{ Species } & \multicolumn{6}{|c|}{ Aboveground } & \multicolumn{6}{|c|}{ Seed Bank } \\
\hline & \multicolumn{3}{|c|}{$\mathrm{CC}$} & \multicolumn{3}{|c|}{ SG } & \multicolumn{3}{|c|}{ CC } & \multicolumn{3}{|c|}{ SG } \\
\hline & SW & INT & $\mathrm{NE}$ & SW & INT & $\mathrm{NE}$ & SW & INT & $\mathrm{NE}$ & SW & INT & NE \\
\hline \multicolumn{13}{|l|}{ Annual or Biennial Herbs } \\
\hline Acalypha rhomboidea & & & & & & & & 2.9 & & 4.9 & 18.5 & 14.3 \\
\hline Amphicarpaea bracteata & 24.2 & 32.4 & 34.5 & 26.8 & 44.4 & 46.4 & & & & & 3.7 & \\
\hline Erechtites hieracifolia & & & & & & & 39.4 & 26.5 & 31.0 & 29.3 & 18.5 & 39.3 \\
\hline Galium aparine & 3.0 & 14.7 & 82.8 & 4.9 & 51.9 & 25.0 & & & & & & \\
\hline Lobelia inflata & & 11.8 & 3.5 & & & & & & & & & \\
\hline *Solanum nigrum & & & & & & & 3.0 & & 13.8 & 2.4 & 3.7 & \\
\hline${ }^{*}$ Verbascum thapsus & & & & & & & 3.0 & & 6.9 & & & 3.6 \\
\hline \multicolumn{13}{|l|}{ Perennial Herbs } \\
\hline Anemonella thalictroides & 3.0 & 5.9 & 17.2 & 2.4 & 7.4 & 17.9 & & & & & & \\
\hline Antennaria plantaginifolia & & 5.9 & & & & & & 2.9 & 24.1 & & & \\
\hline Arisaema triphyllum & & 2.9 & 34.5 & & 18.5 & 21.4 & & & & & & \\
\hline Aristolochia serpentaria & & 8.8 & 3.5 & & 14.8 & 3.6 & & & & & & \\
\hline Aster divaricatus & 51.5 & 55.9 & 3.5 & 29.3 & 37.0 & 50.0 & & & & & & \\
\hline Aster lateriflorus & 57.6 & 76.5 & 24.1 & 24.4 & 33.3 & 7.1 & & & & & & \\
\hline Aster undulatus & 15.2 & 14.7 & & 4.9 & 14.8 & 7.1 & & & & & & \\
\hline Boehmeria cylindrica & 3.0 & 5.9 & 17.2 & 9.8 & 40.7 & 17.9 & & & & & & \\
\hline Botrychium dissectum & & 2.9 & 6.9 & & 11.1 & & & & & & & \\
\hline Cardamine concatenata & & 5.9 & 13.8 & 2.4 & 7.4 & 35.7 & & & & & & \\
\hline * Cardamine hirsuta & & 14.7 & 34.5 & & & & & & 6.0 & & & \\
\hline Cimicifuga racemosa & & 2.9 & 10.3 & & 3.7 & 50.0 & & & & & & \\
\hline Circaea lutetiana & & & 13.8 & & 3.7 & & & & & & & \\
\hline Cunila origanoides & & 23.5 & & 12.2 & & & & & & & & \\
\hline Desmodium glutinosum & 33.3 & 35.3 & 44.8 & 31.7 & 74.1 & 64.3 & & & & & & \\
\hline Dioscorea villosa & & 2.9 & 3.5 & & & 14.3 & & & & & & \\
\hline Dryopteris marginalis & 6.1 & 2.9 & 3.5 & & & 7.1 & & & & & & \\
\hline Eupatorium serotinum & & 5.9 & & & 33.3 & & & 11.8 & 3.5 & 2.4 & 11.1 & \\
\hline Galium circaezans & & 5.9 & 27.6 & 9.8 & 40.7 & 28.6 & & & & & & \\
\hline Geranium maculatum & & 8.8 & 24.1 & 4.9 & 18.5 & 35.7 & & & & & & \\
\hline Geum canadense & & & 3.5 & 2.4 & 40.7 & & & & & & & \\
\hline Goodyera pubescens & & 11.8 & & 7.3 & & & & & & & & \\
\hline Hedyotis caerulea & 9.1 & 5.9 & & 4.9 & & & & & & & & \\
\hline Helianthus divaricatus & & 11.8 & 3.5 & & 7.4 & & & & & & & \\
\hline Heuchera americana & 3.0 & 14.7 & 13.8 & & & & & & & & & 3.5 \\
\hline Hieracium venosum & 9.1 & & & 4.9 & & & & & & & & \\
\hline Hydrophyllum macrophyllum & & & & 2.4 & 3.7 & & & & & & & \\
\hline Lespedeza hirta & 18.2 & 5.9 & & & & & & & & & & \\
\hline Lysimachia quadrifolia & 30.3 & 32.4 & 6.9 & 29.3 & 18.5 & 14.3 & & & & & & \\
\hline Monotropa uniflora & & & & 2.4 & 3.7 & 10.7 & & & & & & \\
\hline Onoclea sensibilis & 3.0 & 8.8 & 6.9 & & & 3.6 & & & & & & \\
\hline Orchis spectabilis & & & 3.5 & & 11.1 & & & & & & & \\
\hline Osmorhiza claytonii & & & 37.9 & & 29.6 & 32.1 & & & & & & \\
\hline Oxalis violacea & & 2.9 & & & 11.1 & & & & & & & \\
\hline Phytolacca americana & 3.0 & & 3.5 & & & & 3.0 & 11.8 & 20.7 & 2.4 & & 3.6 \\
\hline Podophyllum peltatum & & 11.8 & 13.8 & & 14.1 & 7.1 & & & & & & \\
\hline Polygonatum pubescens & 15.2 & 23.5 & 17.2 & 31.7 & 18.5 & 53.6 & & & & & & \\
\hline Polygonum virginianum & & 5.9 & 6.9 & & & & & & & & & \\
\hline
\end{tabular}


Table 3: Continued.

\begin{tabular}{|c|c|c|c|c|c|c|c|c|c|c|c|c|}
\hline \multirow[b]{3}{*}{ Species } & \multicolumn{6}{|c|}{ Aboveground } & \multicolumn{6}{|c|}{ Seed Bank } \\
\hline & \multicolumn{3}{|c|}{$\mathrm{CC}$} & \multicolumn{3}{|c|}{ SG } & \multicolumn{3}{|c|}{$\mathrm{CC}$} & \multicolumn{3}{|c|}{ SG } \\
\hline & SW & INT & $\mathrm{NE}$ & SW & INT & $\mathrm{NE}$ & SW & INT & $\mathrm{NE}$ & SW & INT & $\mathrm{NE}$ \\
\hline Polystichum acrostichoides & 27.3 & 38.2 & 34.5 & 2.4 & 37.4 & 21.4 & & & & & & \\
\hline Porteranthus stipulatus & 12.1 & 2.9 & & 4.9 & & & & & & & & \\
\hline Potentilla simplex & 45.5 & 61.8 & 20.7 & 26.8 & 29.3 & 7.1 & & 5.9 & & 4.9 & 7.4 & 3.6 \\
\hline Prenanthes altissima & 3.0 & 14.7 & 6.9 & 4.9 & 18.2 & 10.7 & & & & & & 3.6 \\
\hline Sanicula canadensis & & & 3.5 & 4.9 & 37.0 & & & & & & & \\
\hline Smilacina racemosa & 9.1 & 17.7 & 17.2 & 19.5 & 11.1 & 25.0 & & & & & & \\
\hline Solidago canadensis & & & & & & & 6.0 & 11.8 & 6.9 & & & \\
\hline * Taraxacum officinale & 6.1 & 14.7 & 3.5 & 2.4 & & & & & & & & \\
\hline Tiarella cordifolia & & & 6.9 & & 3.7 & 21.4 & & & & & & \\
\hline * Trifolium repens & & & & & & & 3.0 & 23.5 & & & 3.7 & \\
\hline Trillium grandiflorum & & 2.9 & 3.5 & & & 10.7 & & & & & & \\
\hline Uvularia perfoliata & & 11.8 & 10.3 & 7.3 & 22.2 & 25.0 & & & & & & \\
\hline Vicia caroliniana & & 23.5 & 17.2 & & & & & & & & & \\
\hline Viola palmata & 3.0 & 5.9 & 17.2 & & & & & & & & & \\
\hline Viola sororia & 30.3 & 44.1 & 44.8 & 22.0 & 48.2 & 14.3 & 3.0 & 2.9 & 3.5 & & 3.7 & 7.1 \\
\hline \multicolumn{13}{|l|}{ Graminoids } \\
\hline Agrostis perennans & & & & & & & 6.1 & 14.7 & 3.5 & & & \\
\hline Bromus pubescens & & 8.8 & 13.8 & 4.9 & 11.1 & 10.7 & & & & & & \\
\hline Carex digitalis & 60.6 & 61.8 & 6.9 & 31.7 & 18.5 & 3.6 & 12.1 & 29.4 & 3.5 & 4.9 & 18.5 & 10.7 \\
\hline Carex laxiflora & 12.1 & 35.3 & 51.7 & 7.3 & 25.9 & 21.4 & 9.1 & 5.9 & 24.1 & 4.9 & 7.4 & 17.9 \\
\hline Juncus tenuis & & 11.8 & & & & & 9.1 & 26.5 & 3.5 & 2.4 & 7.4 & \\
\hline Luzula echinata & & 5.9 & & 7.3 & & & & & & & & \\
\hline Muhlenbergia schreberi & & & & & & & & 2.9 & 6.9 & 2.4 & 3.7 & \\
\hline Panicum boscii & & & & & & & 3.0 & 8.8 & & 12.2 & 7.4 & \\
\hline Panicum clandestinum & 39.4 & 35.3 & 10.3 & 12.2 & 18.5 & & 27.3 & 14.7 & 10.3 & 14.6 & & \\
\hline Panicum dichotomum & 24.2 & 5.9 & & 17.1 & 3.7 & 3.6 & 45.5 & 17.7 & 3.5 & 14.6 & 7.4 & 10.7 \\
\hline Poa sp. & 18.2 & 26.5 & 3.5 & 19.5 & 22.2 & 7.1 & & & & & & \\
\hline \multicolumn{13}{|l|}{ Shrubs and Trees } \\
\hline Acer rubrum & 48.5 & 55.9 & 41.4 & 85.4 & 70.4 & 75.0 & & & & 2.4 & & \\
\hline Amelanchier arborea & 3.0 & 2.9 & & 7.3 & 7.4 & 7.1 & & & & & & \\
\hline Carya spp. & 18.2 & 2.9 & 13.8 & 14.6 & 14.8 & 14.3 & & & & & & \\
\hline Cornus florida & 9.1 & 20.6 & 3.5 & 12.2 & 3.7 & 3.6 & & 2.9 & & & & \\
\hline Fagus grandifolia & 12.1 & 2.9 & & 2.4 & & & & & & & & \\
\hline Fraxinus americana & & & 10.3 & 2.4 & 3.7 & 25.0 & & & & & & \\
\hline Gaylussacia baccata & 18.2 & & & 7.3 & & & & & & & & \\
\hline Lindera benzoin & & 5.9 & 44.8 & & 14.8 & & & & & & & \\
\hline Liriodendron tulipifera & 66.7 & 61.8 & 34.5 & 29.3 & 33.3 & 10.7 & 6.1 & 5.9 & 3.5 & 2.4 & 25.9 & 35.7 \\
\hline Nyssa sylvatica & 27.3 & 8.8 & 10.3 & 17.1 & 18.5 & 14.3 & & 2.9 & & & & \\
\hline Prunus serotina & 6.1 & 20.6 & 17.2 & 9.8 & 7.4 & 7.1 & & & & & & \\
\hline Quercus alba & 18.2 & & & 4.9 & & & & & & & & \\
\hline Quercus prinus & 36.4 & 26.5 & 13.8 & 51.2 & 25.9 & 21.4 & & 2.9 & & 2.4 & & 3.6 \\
\hline Quercus rubra & 24.2 & 26.5 & 24.1 & 39.0 & 29.6 & 21.4 & & & & & & \\
\hline Quercus velutina & 30.3 & & 13.8 & & & & & & & & & \\
\hline Rhus copallinum & 15.2 & 14.7 & 3.5 & & & & & 8.8 & 3.5 & & 7.4 & \\
\hline Rhus glabra & 3.0 & 5.9 & & & & & 3.0 & 5.9 & 6.9 & 4.9 & 11.1 & 14.3 \\
\hline${ }^{*}$ Rosa multiflora & 3.0 & 23.5 & 27.6 & 9.8 & 18.5 & 7.1 & & & & & & \\
\hline Rubus occidentalis & & & & & & & 3.0 & 14.7 & 31.0 & & 7.4 & 3.6 \\
\hline Rubus pensilvanicus & 78.8 & 73.5 & 51.7 & 14.6 & 33.3 & 14.3 & 6.1 & 5.9 & 20.7 & & & 7.1 \\
\hline Sassafras albidum & 66.7 & 55.9 & 20.7 & 80.5 & 70.4 & 28.6 & & & & 2.4 & 7.4 & 3.6 \\
\hline
\end{tabular}


TABle 3: Continued.

\begin{tabular}{|c|c|c|c|c|c|c|c|c|c|c|c|c|}
\hline \multirow[b]{3}{*}{ Species } & \multicolumn{6}{|c|}{ Aboveground } & \multicolumn{6}{|c|}{ Seed Bank } \\
\hline & \multicolumn{3}{|c|}{$\mathrm{CC}$} & \multicolumn{3}{|c|}{ SG } & \multicolumn{3}{|c|}{$\mathrm{CC}$} & \multicolumn{3}{|c|}{ SG } \\
\hline & SW & INT & $\mathrm{NE}$ & SW & INT & $\mathrm{NE}$ & SW & INT & $\mathrm{NE}$ & SW & INT & NE \\
\hline Ulmus rubra & & & & & 40.7 & 3.6 & & & & & & \\
\hline Vaccinium pallidum & 75.8 & 23.5 & & 43.9 & & & & & & & & \\
\hline Vaccinium stamineum & 27.3 & 14.7 & & 43.9 & 14.8 & 3.6 & & & & & & \\
\hline Viburnum acerifolium & 3.0 & 11.8 & 41.4 & 9.8 & 37.0 & 60.7 & & & & & & \\
\hline \multicolumn{13}{|l|}{ Woody Vines } \\
\hline${ }^{*}$ Celastrus orbiculatus & & 5.9 & 6.9 & 2.4 & 7.4 & 7.1 & & & & & & \\
\hline Parthenocissus quinquefolia & 12.1 & 44.1 & 44.8 & 19.5 & 51.9 & 50.0 & & 2.9 & & & & \\
\hline Smilax glauca & 30.3 & 17.7 & 13.8 & 43.9 & 44.4 & 3.6 & & & & & & \\
\hline Smilax rotundifolia & 81.8 & 55.9 & 48.3 & 70.7 & 44.4 & 32.1 & 6.1 & & & & 3.7 & 3.6 \\
\hline Toxicodendron radicans & & 8.8 & 3.5 & & 3.7 & 10.7 & & & & & & \\
\hline Vitis vulpina & 42.4 & 35.3 & 58.6 & 19.5 & 14.8 & 14.3 & 6.1 & 2.9 & 3.5 & 7.3 & 14.8 & 7.1 \\
\hline
\end{tabular}

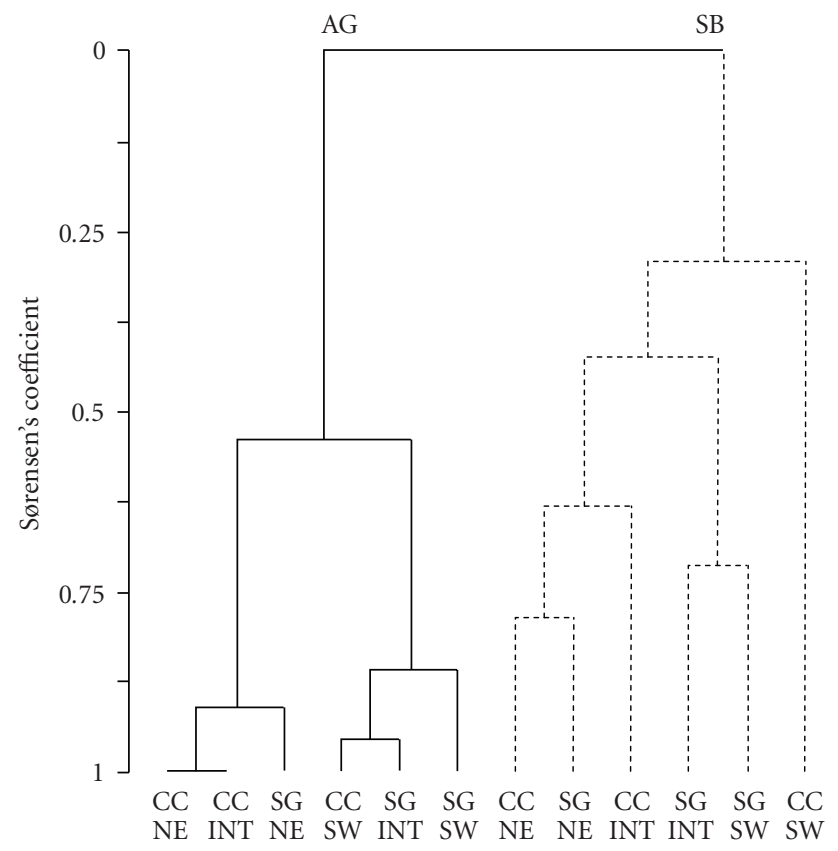

Figure 5: Summary dendrogram representing UPGMA cluster analysis of aboveground (AG; solid) and seed bank (SB; broken) samples across the six stand age/aspect classes examined. (See text for description of aspect/stand age classes.)

the primary influence on seed bank richness, but that seeds are likely to persist from earlier land use disturbances (esp. former cultivation or pasturing) or dispersal from nearby open habitats $[15,16]$. Supporting this view, Schiffman and Johnson [24] attribute notably low seed diversity and density in mature oak-dominated forests of the southern Appalachians to the absence of such disturbance history and neighboring seed sources.

Alternative explanations for the high seed bank richness found at our study site support assertions of undersampling in many temperate forest seed bank studies. High variability in seed bank composition, density, and diversity is frequently

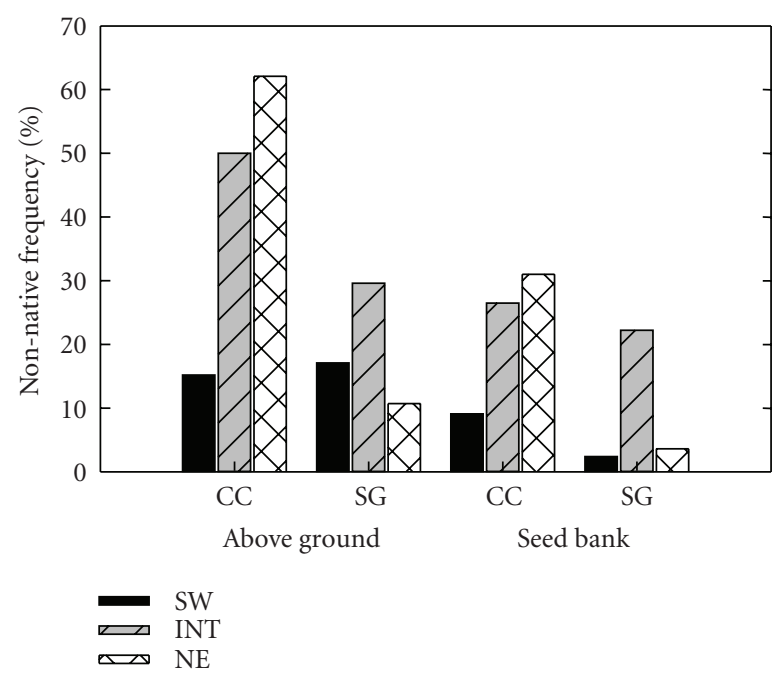

FIGURE 6: Frequency of nonnative plant species in aboveground and seed bank samples across the six stand age/aspect classes examined. (See text for description of classes.)

reported, coupled with low observed richness values [15]. However, assessments of sampling adequacy are rarely performed [70-72]. In our study, nearly 200 seed bank samples (96 per stand type; $0.01 \mathrm{~m}^{2}$ ) were insufficient (based on Jackknife richness estimations) to fully capture seed bank heterogeneity, yet we sampled much more intensively than many similar studies. For example, Olmsted and Curtis [61] found 10, 12, and 8 seed bank species in 50, 110, and 150 year beech-sugar maple stands in Maine, but their study included only four $0.09 \mathrm{~m}^{2}$ samples from each stand. Ashton et al. [27] found 25 seed bank species in 70-90 year deciduous forests of southern New England, based on 36-0.01 $\mathrm{m}^{2}$ samples. Similarly, Roberts and Vankat [69] reported 29 taxa in a 10year-old field, 21 taxa in a 90 year, and 14 taxa in an oldgrowth beech-maple forest in western Ohio, based on 10$0.008 \mathrm{~m}^{2}$ samples from each sere. Like our study, each of these reflects seed bank samples collected in winter or early 
spring, before spring germination, and therefore includes both transient seed bank species (those viable only in the first year after maturation and dispersal) and persistent seed bank species (viable seeds persisting in the seed bank for more than one year [44]). Given the high compositional variation of our seed bank samples (Figures 2 and 5) and failure of our species-area curves to reach plateaus (Figure 1), sample sizes such as these would have severely decreased observed richness values (e.g., a sample size of $n=10$ would have resulted in only 14 and 20 spp., instead of the 46 (SG) and 49 (CC) spp. observed) and potentially biased observed trends. Similar conclusions were reached by Qi and Scarratt [72], in a study of clearcut and undisturbed boreal mixedwood forest of Ontario, and Stark et al. [70], in an evaluation of seed bank variability and sampling adequacy in Douglas-fir forests of British Columbia, each emphasizing the need for intensive sampling to represent seed bank heterogeneity and the pronounced influence of infrequent (unique) species.

4.4. Influence of Topography on Seed Bank Composition. We found seed bank composition, including the prevalence of nonnative species, to vary markedly with topographic aspect position (i.e., SW versus NE slopes; Figure 5). All aspect/stand age classes were dominated by ruderal herbs (e.g., Erechtites hieraciifolia, Acalypha rhomboidea, and Solanum nigrum), but grasses (esp. Panicum spp.) were especially common in the soils of SW slopes; thicket-forming shrubs (Rubus spp., Rhus spp.) were better represented in NE and INT slope soils. Two early-successional, shade-intolerant trees (Liriodendron tulipifera and Sassafras albidum) were also important in NE and INT forest seed banks. As in many north temperate regions, aspect differences across our study site are associated with edaphic variations, with drier, more acidic, and less fertile soils on SW slopes (lower organic matter, nutrient content (esp. Ca, K, Mg), Ca: Al ratio, and higher $\mathrm{C}: \mathrm{N}$ ratio) versus INT or NE slopes, regardless of stand age $[37,41]$. The highest soil nutrient concentrations occur in NE-CC soils and INT-SG soils; [41]. Like Jenkins and Parker [34, 38] in hardwood forests of central Indiana and Hutchinson et al. [33] in nearby oak forests of southern Ohio, we found site quality (slope aspect) to be a primary influence on aboveground structure and composition, with greater woody seedling abundance, lower herbaceous richness and abundance, and lower canopy tree density and basal area on SW slopes [41] (Figure 4).

Similar variations in seed bank size and composition have been noted relative to specific soil or site factors (e.g., soil $\mathrm{pH}$, moisture, and organic content $[13,17])$, yet few studies have considered the implications of broader scale landscape variations. An exception is Ashton et al. [27], who examined seed bank dynamics along topographic gradients from ridgetop to valley bottom and reported differences in seed density, diversity, and life form frequency relative to slope position. Such differences in seed bank composition across the landscape, as found in our study (Figures 4 and 5), should be expected to produce compositional and potentially structural differences in early-successional communities following disturbance. These initial communities, in turn, play an important role in shaping the competitive environment for overstory regeneration. George and Bazzaz [19] demonstrated this pronounced influence of ground layer competition (intense fern competition) on tree seedlings in mixed hardwood forests of central Massachusetts. They concluded that understory vegetation can act as a speciesspecific "filter" to tree seedling emergence, growth, and survival, shaping the structure and composition of seedling communities and potentially driving compositional shifts in tree regeneration. Similar effects on sapling growth and survival have been noted under thick shrub (Rhododendron maximum) cover in the southern Appalachians [19, 73]. While perennial herbs were relatively infrequent in our seed bank samples, greater prevalence of thicket-forming shrubs and early-successional trees on NE slopes suggests greater potential for regeneration inhibition on these mesic sites.

The effects of understory competition on regeneration of desired timber species, especially during stand initiation, are considered critical aspects of forest management [23, 74]. Successful canopy reestablishment is dependent on a number of factors, including the availability of advance regeneration, understory density and composition, and site conditions [21, 22, 74-76]. In eastern deciduous forests, poor oak regeneration (esp. Quercus rubra and Q. alba) has become a major concern, with intense understory competition considered a primary cause of regeneration failure after harvesting, particularly on high quality sites [22, 23]. Dense understories of shade-tolerant and faster-growing saplings (e.g., Acer saccharum, A. rubrum, Liriodendron tulipifera, Fraxinus americana, Nyssa sylvatica, and Sassafras albidum), shrubs (e.g., Rhododendron maximum), and taller, broadleaved herbs have been shown to slow growth and increase mortality of oak seedlings and encourage replacement of oak-dominated stands by more mesophytic species $[23,38$, 73, 74, 77]. On mesic sites, logging and canopy-opening disturbances tend to accelerate this transition by releasing shade-tolerant species already present in the understory [38, 74, 78].

Our results similarly suggest that canopy removal and soil disturbance may be more problematic in mesic and intermediate stands (NE/INT slopes) at our study site, where they are likely to favor emergence of rapid growing and highly competitive saplings (e.g., Liriodendron tulipifera, Sassafras albidum), shrubs (e.g., Rubus spp., Rhus spp., and Smilax rotundifolia), and broad-leaved herbs (versus grasses) from the soil seed bank (Table 3). Disturbance of mesic sites also appears to encourage nonnative species establishment, with the greatest frequencies of nonnatives on sites of higher soil moisture and fertility (NE and INT slopes) and more recent disturbance (CC) at our study site (Figure 6, Table 3). Increased frequency of nonnative seeds and aboveground species on mesic, disturbed sites supports the results of $\mathrm{McNab}$ and Loftis [79] and Neary et al. [80], who emphasize the importance of minimizing soil disturbance on richer sites, where the potential for aggressive competitors is especially high during stand initiation.

Our findings generally support the results of other temperate forest seed bank studies, suggesting similar dynamics but potentially greater seed bank diversity in the mixed 
mesophytic forest region. Yet our study also emphasizes the need for increased attention to sources of ecological heterogeneity, their assessment, and their influences on seed bank dynamics, as these may have important implications for postharvest regeneration in eastern forests. Dech et al. [23] describe variations in initial understory composition, including oak seedling competitors, with harvesting intensity and topographically driven gradients of soil fertility and similarly emphasize the importance of ecosystem-specific considerations in the management of overstory regeneration. Understanding controls on understory development after forest clearing, particularly factors influencing the density and composition of competing ground layer vegetation, is one of the most important knowledge gaps in our understanding of oak regeneration. Seed bank communities are likely to play an important, site-dependent role in shaping the competitive environment for oaks and other commercially important timber species after harvesting and, thereby, have the potential to influence postharvest forest development. As seed bank contributions are expected to increase with soil disturbance and seed composition has been shown to vary with the specific properties of the forest system, our results emphasize the importance of site-specific management in assessing the potential for soil disturbance and resulting understory competition to inhibit overstory regeneration success.

\section{Acknowledgments}

The authors wish to thank the Ohio Biological Survey, Ohio University Houk Memorial Research Fund, and the Department of Environmental and Plant Biology at Ohio University for financial support, the Waterloo Wildlife Research Station, ODNR for permission to conduct this study, and J. E. Brown, D. C. White, and R. G. Verb for field assistance.

\section{References}

[1] P. M. Attiwill, "The disturbance of forest ecosystems: the ecological basis for conservative management," Forest Ecology and Management, vol. 63, no. 2-3, pp. 247-300, 1994.

[2] J. Aber, N. L. Christensen, I. Fernandez, et al., "Applying ecological principles to management of the US National Forests," Issues in Ecology, vol. 6, pp. 1-20, 2000.

[3] J. F. Franklin, T. A. Spies, R. V. Pelt, et al., "Disturbances and structural development of natural forest ecosystems with silvicultural implications, using Douglas-fir forests as an example," Forest Ecology and Management, vol. 155, no. 1-3, pp. 399-423, 2002.

[4] C. R. Drever, G. Peterson, C. Messier, Y. Bergeron, and M. Flannigan, "Can forest management based on natural disturbances maintain ecological resilience?" Canadian Journal of Forest Research, vol. 36, no. 9, pp. 2285-2299, 2006.

[5] C. D. Oliver and B. C. Larson, Forest Stand Dynamics, McGraw-Hill, New York, NY, USA, 1990.

[6] A. A. Royo and W. P. Carson, "On the formation of dense understory layers in forests worldwide: consequences and implications for forest dynamics, biodiversity, and succession," Canadian Journal of Forest Research, vol. 36, no. 6, pp. 13451362, 2006.
[7] G. E. Likens, F. H. Bormann, R. S. Pierce, and W. A. Reiners, "Recovery of a deforested ecosystem," Science, vol. 199, no. 4328, pp. 492-496, 1978.

[8] H. F. Bormann and G. E. Likens, Pattern and Process in a Forest Ecosystem, Springer, New York, NY, USA, 1979.

[9] M. R. Roberts and F. S. Gilliam, "Disturbance effects on herbaceous layer vegetation and soil nutrients in Populus forests of northern lower Michigan," Journal of Vegetation Science, vol. 6, no. 6, pp. 903-912, 1995.

[10] P. Mayer, C. Abs, and A. Fischer, "Colonisation by vascular plants after soil disturbance in the Bavarian Forest-key factors and relevance for forest dynamics," Forest Ecology and Management, vol. 188, no. 1-3, pp. 279-289, 2004.

[11] M. Zobel, R. Kalamees, K. Püssa, E. Roosaluste, and M. Moora, "Soil seed bank and vegetation in mixed coniferous forest stands with different disturbance regimes," Forest Ecology and Management, vol. 250, no. 1-2, pp. 71-76, 2007.

[12] D. A. Marquis, "Seed storage and germination under northern hardwood forests," Journal of Forest Research, vol. 5, pp. 478484, 1975.

[13] A. H. F. Brown and L. Oosterhuist, "The role of buried seed in coppicewoods," Biological Conservation, vol. 21, no. 1, pp. 19-38, 1981.

[14] K. Thompson, "The functional ecology of seed banks," in Seeds: The Ecology of Regeneration in Plant Communities, M. Fenner, Ed., pp. 231-258, CAB International, London, UK, 1992.

[15] S. T. A. Pickett and M. J. McDonnell, "Seed bank dynamics in temperate deciduous forests," in Ecology of Soil Seed Banks, M. A. Leck, V. T. Parker, and R. L. Simpson, Eds., pp. 123-147, Academic Press, New York, NY, USA, 1989.

[16] L. A. Hyatt and B. B. Casper, "Seed bank formation during early secondary succession in a temperate deciduous forest," Journal of Ecology, vol. 88, no. 3, pp. 516-527, 2000.

[17] S. Leckie, M. Vellend, G. Bell, M. J. Waterway, and M. J. Lechowicz, "The seed bank in an old-growth, temperate deciduous forest," Canadian Journal of Botany, vol. 78, no. 2, pp. 181-192, 2000.

[18] U. Grandin, "Short-term and long-term variation in seed bank/vegetation relations along an environmental and successional gradient," Ecography, vol. 24, no. 6, pp. 731-741, 2001.

[19] L. O. George and F. A. Bazzaz, "The herbaceous layer as a filter determining spatial pattern in forest tree regeneration," in The Herbaceous Layer in Forests of Eastern North America, F. S. Gilliam and M. R. Roberts, Eds., pp. 265-282, Oxford University Press, Oxford, UK, 2003.

[20] F. S. Gilliam, "The ecological significance of the herbaceous layer in temperate forest ecosystems," BioScience, vol. 57, no. 10, pp. 845-858, 2007.

[21] R. R. Hicks, Ecology and Management of Central Hardwood Forests, John Wiley \& Sons, New York, NY, USA, 1998.

[22] D. L. Loftis, "Regenerating northern red oak on high-quality sites in the southern Appalachians," in Oak Regeneration: Serious Problems, Practical Recommendations, D. Loftis and C. E. McGee, Eds., pp. 202-210, USDA Forest Service, Southeastern Forest Experiment Station, Asheville, NC, USA, 1993, General Technical Report SE-84.

[23] J. P. Dech, L. M. Robinson, and P. Nosko, "Understorey plant community characteristics and natural hardwood regeneration under three partial harvest treatments applied in a northern red oak (Quercus rubra L.) stand in the Great LakesSt. Lawrence forest region of Canada," Forest Ecology and Management, vol. 256, no. 4, pp. 760-773, 2008. 
[24] P. M. Schiffman and W. C. Johnson, "Sparse buried seed banks in a southern Appalachian oak forest: implications for succession," American Midland Naturalist, vol. 127, pp. 258267, 1992.

[25] R. E. Landenberger and J. B. McGraw, "Seed-bank characteristics in mixed-mesophytic forest clearcuts and edges: does "edge effect" extend to the seed bank?" Canadian Journal of Botany, vol. 82, no. 7, pp. 992-1000, 2004.

[26] L. R. Schelling and B. C. McCarthy, "Effects of prescribed fire and thinning on the spatial heterogeneity of the seed bank in a mixed oak forest," Natural Areas Journal, vol. 27, no. 4, pp. 320-331, 2007.

[27] P. M. S. Ashton, P. G. Harris, and R. Thadani, "Soil seed bank dynamics in relation to topographic position of a mixeddeciduous forest in southern New England, USA," Forest Ecology and Management, vol. 111, no. 1, pp. 15-22, 1998.

[28] J. E. Cantlon, "Vegetation and microclimates on north and south slopes of Cushetunk Mountain, New Jersey," Ecological Monographs, vol. 23, pp. 241-270, 1953.

[29] D. P. Franzmeier, E. J. Pedersen, T. J. Longwell, J. G. Byrne, and C. K. Losche, "Properties of some soils in the Cumberland Plateaus as related to slope aspect and topography," Proceedings of the Soil Science Society of America, vol. 33, no. 5, pp. 755-761, 1969.

[30] R. R. Hicks Jr. and P. S. Frank Jr., "Relationship of aspect to soil nutrients, species importance and biomass in a forested watershed in West Virginia," Forest Ecology and Management, vol. 8, no. 3-4, pp. 281-291, 1984.

[31] F. Desta, J. J. Colbert, J. S. Rentch, and K. W. Gottschalk, "Aspect induced differences in vegetation, soil, and microclimatic characteristics of an Appalachian watershed," Castanea, vol. 69, no. 2, pp. 92-108, 2004.

[32] R. E. J. Boerner, "Unraveling the Gordian Knot: interactions among vegetation, topography, and soil properties in the central and southern Appalachians," Journal of the Torrey Botanical Society, vol. 133, no. 2, pp. 321-361, 2006.

[33] T. F. Hutchinson, R. E. J. Boerner, L. R. Iverson, S. Sutherland, and E. K. Sutherland, "Landscape patterns of understory composition and richness across a moisture and nitrogen mineralization gradient in Ohio (U.S.A.) Quercus forests," Plant Ecology, vol. 144, no. 2, pp. 177-189, 1999.

[34] M. A. Jenkins and G. R. Parker, "Composition and diversity of ground-layer vegetation in silvicultural openings of southern Indiana forests," American Midland Naturalist, vol. 142, no. 1, pp. 1-16, 1999.

[35] B. C. McCarthy, C. J. Small, and D. L. Rubino, "Composition, structure and dynamics of Dysart Woods, an old-growth mixed mesophytic forest of southeastern Ohio," Forest Ecology and Management, vol. 140, no. 2-3, pp. 193-213, 2001.

[36] B. C. McCarthy, "The herbaceous layer of eastern old-growth deciduous forests," in The Herbaceous Layer in Forests of Eastern North America, F. S. Gilliam and M. R. Roberts, Eds., pp. 163-176, Oxford University Press, Oxford, UK, 2003.

[37] C. J. Small and B. C. McCarthy, "Relationship of understory diversity to soil nitrogen, topographic variation, and stand age in an eastern oak forest, USA," Forest Ecology and Management, vol. 217, no. 2-3, pp. 229-243, 2005.

[38] M. A. Jenkins and G. R. Parker, "Composition and diversity of woody vegetation in silvicultural openings of southern Indiana forests," Forest Ecology and Management, vol. 109, no. 1-3, pp. 57-74, 1998.

[39] E. L. Braun, Deciduous Forests of Eastern North America, Hafner Press/Macmillan, New York, NY, USA, 1950.
[40] C. S. Brockman, Physiographic Regions of Ohio, Ohio Department of Natural Resources, Columbus, Ohio, USA, 1998.

[41] C. J. Small and B. C. McCarthy, "Spatial and temporal variation in the response of understory vegetation to disturbance in a central Appalachian oak forest," Journal of the Torrey Botanical Society, vol. 129, no. 2, pp. 136-153, 2002.

[42] R. L. Simpson, M. A. Leck, and V. T. Parker, "Seed banks: general concepts and methodological issues," in Ecology of Soil Seed Banks, M. A. Leck, V. T. Parker, and R. L. Simpson, Eds., pp. 3-8, Academic Press, New York, NY, USA, 1989.

[43] D. Brown, "Estimating the composition of a forest seed bank: a comparison of the seed extraction and seedling emergence methods," Canadian Journal of Botany, vol. 70, no. 8, pp. 16031612, 1992.

[44] J. M. Baskin and C. C. Baskin, Seeds: Ecology, Biogeography, and Evolution of Dormancy and Germination, Academic Press, San Diego, Calif, USA, 2001.

[45] G. N. J. Ter Heerdt, G. L. Verweij, R. M. Bekker, and J. P. Bakker, "An improved method for seed-bank analysis: seedling emergence after removing the soil by sieving," Functional Ecology, vol. 10, no. 1, pp. 144-151, 1996.

[46] C. R. Malone, "A rapid method for enumeration of viable seeds in soil," Weeds, vol. 15, pp. 381-382, 1967.

[47] D. B. MacKay, "The measurement of viability," in Viability of Seeds, E. H. Roberts, Ed., pp. 172-208, Chapman and Hall, London, UK, 1972.

[48] H. A. Gleason and A. Cronquist, Manual of Vascular Plants of Northeastern United States and Adjacent Canada, The New York Botanical Garden, Bronx, NY, USA, 2nd edition, 1991.

[49] J. L. Hintze, Number Cruncher Statistical Software (NCSS) 2000, NCSS, Kaysville, Utah, USA, 2000.

[50] J. F. Heltshe and N. E. Forrester, "Estimating species richness using the jackknife procedure," Biometrics, vol. 39, no. 1, pp. $1-11,1983$.

[51] M. W. Palmer, "The estimation of species richness by extrapolation,” Ecology, vol. 71, pp. 1195-1198, 1990.

[52] K. P. Burnham and W. S. Overton, "Robust estimation of population size when capture probabilities vary among animals," Ecology, vol. 60, pp. 927-936, 1979.

[53] M. W. Palmer, "Estimating species richness: the second-order jackknife reconsidered," Ecology, vol. 72, pp. 1512-1513, 1991.

[54] R. L. Chazdon, R. K. Colwell, J. S. Denslow, and M. R. Guariguata, "Statistical methods for estimating species richness of woody regeneration in primary and secondary rain forests of northeastern Costa Rica," in Forest Biodiversity Research, Monitoring, and Modeling: Conceptual Background and Old World Case Studies, F. Dallmeier and J. A. Comiskey, Eds., pp. 285-309, Smithsonian Institution, Washington, DC, USA, 1998.

[55] B. McCune and M. J. Mefford, PC-ORD for Windows: Multivariate Analysis of Ecological Data, version 4.35, MjM Software, Gleneden Beach, Ore, USA, 1999.

[56] H. G. Gauch, Multivariate Analysis in Community Ecology, Cambridge University Press, New York, NY, USA, 1982.

[57] C. J. F. Ter Braak, "Canonical correspondence analysis: a new eigenvector technique for multivariate direct gradient analysis," Ecology, vol. 67, no. 5, pp. 1167-1179, 1986.

[58] T. W. Beers, P. E. Dress, and L. C. Wensel, "Aspect transformation in site productivity research," Journal of Forestry, vol. 64, pp. 691-692, 1966.

[59] M. W. Palmer, "Putting things in even better order: the advantages of canonical correspondence analysis," Ecology, vol. 74, no. 8, pp. 2215-2230, 1993. 
[60] H. F. Oosting and M. E. Humphreys, "Buried viable seeds in successional series of old fields and forest soils," Bulletin of the Torrey Botanical Club, vol. 67, pp. 253-273, 1940.

[61] N. W. Olmsted and J. D. Curtis, "Seeds of the forest floor," Ecology, vol. 28, pp. 49-53, 1947.

[62] K. Thompson and J. P. Grime, "Seasonal variation in the seed banks of herbaceous species in ten contrasting habitats," Journal of Ecology, vol. 67, pp. 893-921, 1979.

[63] G. Decocq, B. Valentin, B. Toussaint, F. Hendoux, R. Saguez, and J. Bardat, "Soil seed bank composition and diversity in a managed temperate deciduous forest," Biodiversity and Conservation, vol. 13, no. 13, pp. 2485-2509, 2004.

[64] D. Tillman, "The resource-ratio hypothesis of plant succession," American Naturalist, vol. 125, no. 6, pp. 827-852, 1985.

[65] P. S. White and S. T. A. Pickett, "Natural disturbance and patch dynamics: an introduction," in The Ecology of Natural Disturbance and Patch Dynamics, S. T. A. Pickett and P. S. White, Eds., pp. 3-13, Academic Press, Orlando, Fla, USA, 1985.

[66] R. J. Hobbs, "The nature and effects of disturbance relative to invasions," in Biological Invasion: A Global Perspective, J. A. Drake, F. Di Castri, R. H. Groves, and F. J. Kruger, Eds., pp. 389-405, John Wiley \& Sons, New York, NY, USA, 1989.

[67] M. A. Davis, J. P. Grime, and K. Thompson, "Fluctuating resources in plant communities: a general theory of invasibility," Journal of Ecology, vol. 88, no. 3, pp. 528-534, 2000.

[68] B. S. Collins, K. P. Dunne, and S. T. A. Pickett, "Responses of forest herbs to canopy gaps," in The Ecology of Natural Disturbance and Patch Dynamics, S. T. A. Pickett and P. S. White, Eds., pp. 217-234, Academic Press, Orlando, Fla, USA, 1985.

[69] T. L. Roberts and J. L. Vankat, "Floristics of a chronosequence corresponding to old field-deciduous forest succession in southwestern Ohio. II. Seed banks," Bulletin of the Torrey Botanical Club, vol. 118, no. 4, pp. 377-384, 1991.

[70] K. E. Stark, A. Arsenault, and G. E. Bradfield, "Variation in soil seed bank species composition of a dry coniferous forest: spatial scale and sampling considerations," Plant Ecology, vol. 197, no. 2, pp. 173-181, 2008.

[71] F. Forcella, "A species-area curve for buried viable seeds," Australian Journal of Agricultural Research, vol. 35, no. 5, pp. 645-652, 1984.

[72] M. Qi and J. B. Scarratt, "Effect of harvesting method on seed bank dynamics in a boreal mixedwood forest in northwestern Ontario," Canadian Journal of Botany, vol. 76, no. 5, pp. 872883, 1998.

[73] B. Beckage, B. D. Kloeppel, J. A. Yeakley, S. F. Taylor, and D. C. Coleman, "Differential effects of understory and overstory gaps on tree regeneration," Journal of the Torrey Botanical Society, vol. 135, no. 1, pp. 1-11, 2008.

[74] C. G. Lorimer, J. W. Chapman, and W. D. Lambert, "Tall understorey vegetation as a factor in the poor development of oak seedlings beneath mature stands," Journal of Ecology, vol. 82, no. 2, pp. 227-237, 1994.

[75] P. Brose, D. Van Lear, and R. Cooper, "Using shelterwood harvests and prescribed fire to regenerate oak stands on productive upland sites," Forest Ecology and Management, vol. 113, no. 2-3, pp. 125-141, 1999.

[76] T. M. Schuler, "Fifty years of partial harvesting in a mixed mesophytic forest: composition and productivity," Canadian Journal of Forest Research, vol. 34, no. 5, pp. 985-997, 2004.

[77] L. R. Iverson, T. F. Hutchinson, A. M. Prasad, and M. P. Peters, "Thinning, fire, and oak regeneration across a heterogeneous landscape in the eastern U.S.: 7-year results," Forest Ecology and Management, vol. 255, no. 7, pp. 3035-3050, 2008.

[78] D. E. Beck and R. M. Hooper, "Development of a southern Appalachian hardwood stand after clearcutting," Southern Journal of Applied Forestry, vol. 10, no. 3, pp. 168-172, 1986.

[79] W. H. McNab and D. L. Loftis, "Probability of occurrence and habitat features for oriental bittersweet in an oak forest in the southern Appalachian mountains, USA," Forest Ecology and Management, vol. 155, no. 1-3, pp. 45-54, 2002.

[80] D. G. Neary, S. T. Overby, and W. H. Moir, "Role of soil disturbances in determining post-harvest plant biodiversity and invasive weed distributions ," in Popular Summaries from the Fourth International Conference on Forest Vegetation Management, H. Frochot, C. Collet, and P. Balandier, Eds., pp. 52-54, Institut National de la Recherche Agronomique, Nancy, France, 2002. 

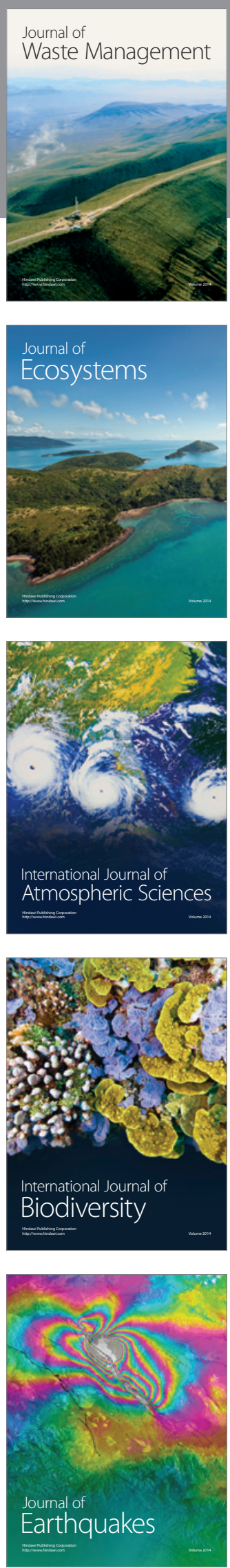
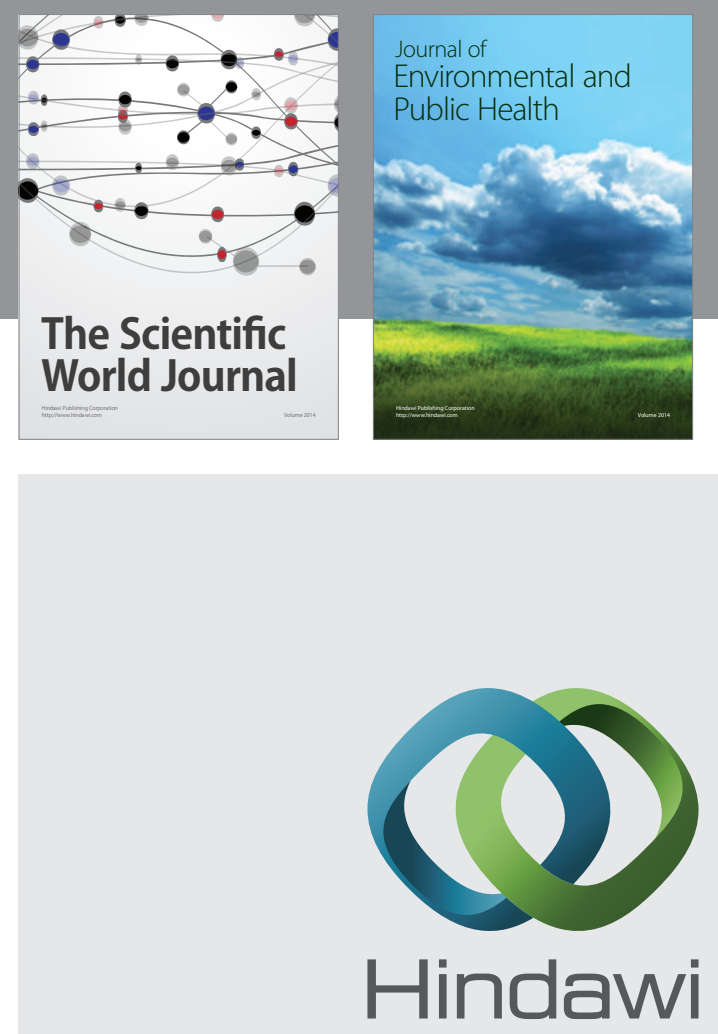

Submit your manuscripts at

http://www.hindawi.com
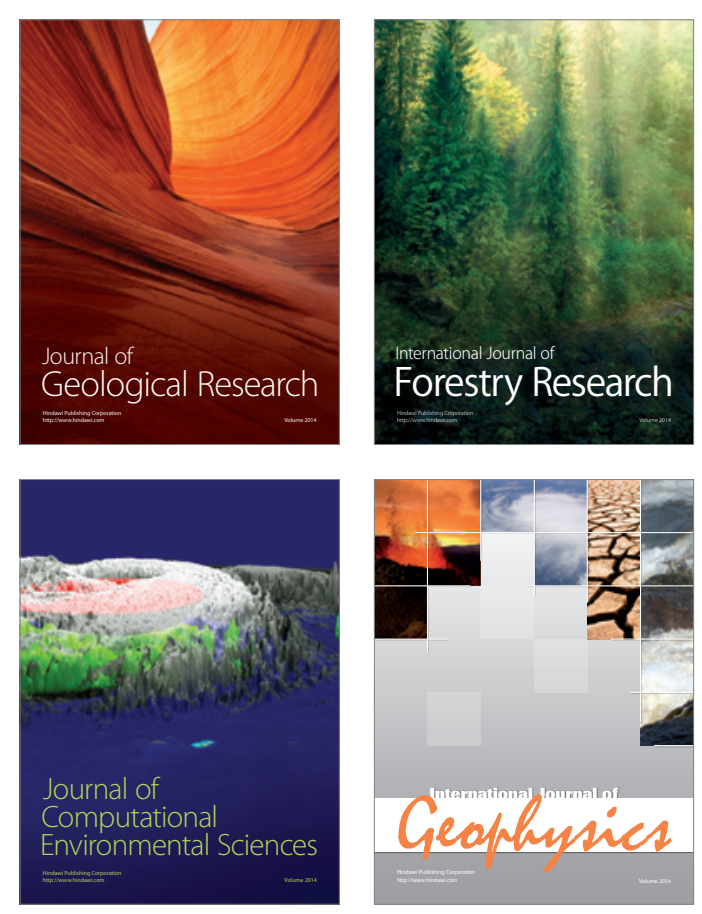
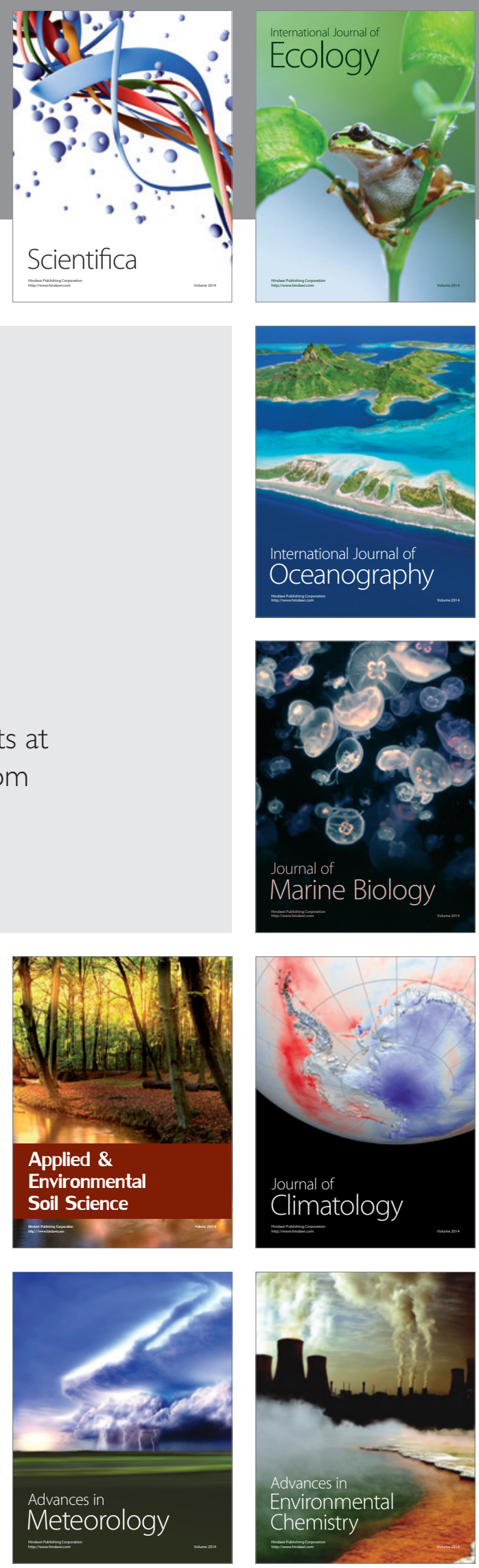